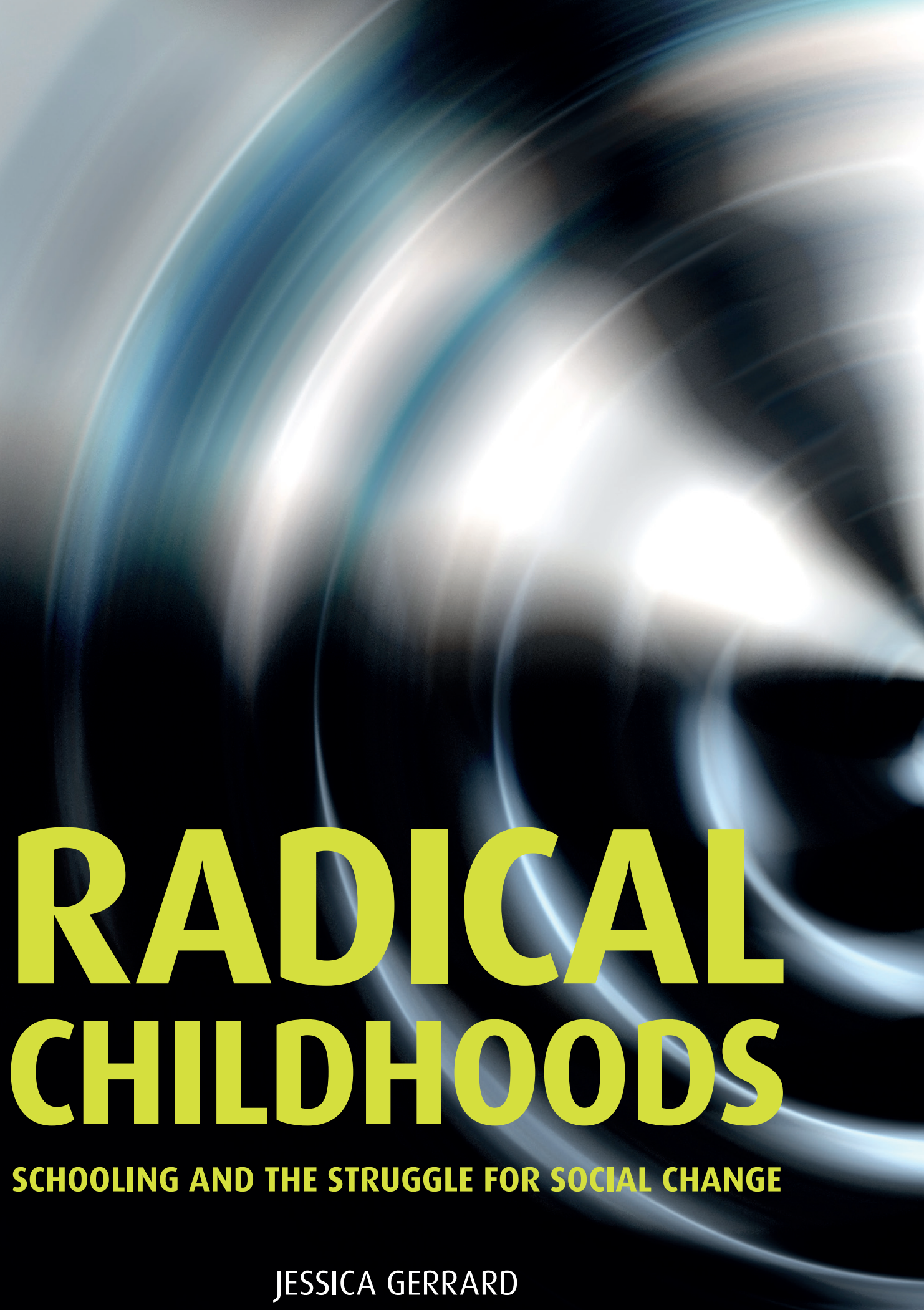




\section{Radical childhoods}

\section{MANCHESTER 1824}

Manchester University Press 
Jessica Gerrard - 9781526111753

Downloaded from manchesterhive.com at $04 / 26 / 2023$ ०9:०8:15AM 


\title{
Radical childhoods
}

\section{Schooling and the struggle for social change}

\author{
JESSICA GERRARD
}

Manchester University Press

Manchester and New York

distributed exclusively in the USA by Palgrave Macmillan 
Copyright (C) Jessica Gerrard 2014

The right of Jessica Gerrard to be identified as the author of this work has been asserted by her in accordance with the Copyright, Designs and Patents Act 1988.

Published by Manchester University Press

Oxford Road, Manchester M13 9NR, UK

and Room 400, 175 Fifth Avenue, New York, NY 10010, USA

www.manchesteruniversitypress.co.uk

Distributed exclusively in the USA by

Palgrave Macmillan, 175 Fifth Avenue, New York,

NY 10010, USA

Distributed exclusively in Canada by

UBC Press, University of British Columbia, 2029 West Mall, Vancouver, BC, Canada V6T 1 Z2

British Library Cataloguing-in-Publication Data

A catalogue record for this book is available from the British Library

Library of Congress Cataloging-in-Publication Data applied for

ISBN 9780719090219 hardback

First published 2014

The publisher has no responsibility for the persistence or accuracy of URLs for external or any third-party internet websites referred to in this book, and does not guarantee that any content on such websites is, or will remain, accurate or appropriate.

Typeset in Arno Pro by

Koinonia, Manchester 